\title{
Effects of Ionic solutions in Water Treeing Propagation of XLPE Insulated HV Cable by Using ANSYS MAXWELL 2D
}

\author{
Narupon Promvichai ${ }^{a}$, Kelvin Melckzedeck Minja ${ }^{a}$, Pius Victor Chombo ${ }^{a}$, Tassanai Supanarapan ${ }^{a}$, \\ Terapong Boonraksa ${ }^{\mathrm{b}}$ and Boonruang Marungsri ${ }^{\mathrm{a}, *}$ \\ ${ }^{\text {a }}$ School of Electrical Engineering, Suranaree University of Technology, \\ Nakhon Ratchasima 30000, Thailand. \\ ${ }^{\mathrm{b}}$ School of Electrical Engineering, Rajamangala University of Technology Rattanakosin, Salaya Phutthamonthon, \\ Nakhon Pathom 73170, Thailand. \\ *Corresponding Author: bmshvee@sut.ac.th
}

\begin{abstract}
Most of the distribution systems are nowadays upgraded to underground systems. Cross-linked polyethylene (XLPE) insulation has been employed as an insulator in underground power cables due to its excellence in electrical properties. The environmental issues in service have been the major studied problem that associated with the formation of water treeing and reduction of XLPE insulation performance. In the humid underground environment where XLPE power cables are laid, a number of ionic solutions can be found which in the presence of water treeing can lead the aging process. This paper studies the effects of electric fields in the presence of $\mathrm{Cu}\left(\mathrm{NO}_{3}\right)_{2}$, $\mathrm{CuSO}_{4}, \mathrm{FeSO}_{4}, \mathrm{~K}_{2} \mathrm{SO}_{4}, \mathrm{Na}_{2} \mathrm{SO}_{4}$, and $\mathrm{NaCl}$ solutions with water treeing radius of $0.1,0.5,1.0$ and $1.5 \mathrm{~mm}$ in ANSYS MAXWELL 2D. Bush type water treeing resulted into 31 $\mathrm{kV} / \mathrm{mm}$ in $1.5 \mathrm{~mm}$ radius with $\mathrm{Cu}\left(\mathrm{NO}_{3}\right)_{2}, \mathrm{FeSO}_{4}, \mathrm{~K}_{2} \mathrm{SO}_{4}$, $\mathrm{Na}_{2} \mathrm{SO}_{4}$, and $\mathrm{NaCl}$ solution. In vented type water treeing, 38 $\mathrm{kV} / \mathrm{mm}$ in $1.5 \mathrm{~mm}$ radius with $\mathrm{CuSO} 4$, was observed. The observed field strengths were above the minimum acceptable breakdown voltage $(30 \mathrm{kV} / \mathrm{mm})$ of XLPE insulation but $\mathrm{CuSO}_{4}$ solutions showed great contribution in the intensification of electric fields.
\end{abstract}

Keywords: Water treeing, Electrical tree, Electric field, XLPE power cable, ANSYS MAXWELL 2D.

\section{Introduction}

Water treeing in underground power cable is described as an electrochemical treeing process in presence of ionic solutions which cause distortion due to partial discharge and progressing through layers under electric stress in extremely non-uniform fields ${ }^{(1)}$. It is a major source of causes ageing of polymeric cable insulation apart from thermal degradation, partial discharges, aggression by environment and losses ${ }^{(2)}$. Cross-linked polyethylene (XLPE) is widely used as insulation in underground high tension cables but a damaging phenomenon called treeing takes place inside the material with continued exposure to moisture and electrical stress ${ }^{(3-6)}$. The study of inception and extent of the growth of water treeing to electrical treeing have been examined and analyzed in Wang et al. ${ }^{(7)}$; Boggs et al. $^{(8)}$; Assay ${ }^{(9)}$. They aimed to evaluate acceleration ageing and improve the high performance of insulation material by considering the dimensions of water treeing, ageing structural changes, the concentration of the electrolyte, type of applied voltage and temperature on inception voltage of electrical tree.

When XLPE cable is subjected to lightning or switching overvoltage, there is a high possibility for water treeing to become electrical treeing ${ }^{(7-8)}$. Ref. $^{(10)}$ defined the applied voltage as a source of external forces (electric fields) that squeezes ionic solutions into small cracks and weak points of the XLPE cable. The presence of ionic solutions in small cracks and/or weak points causes the formation of water treeing. The tips of growing water treeing experience the different strength of electric fields. The theory about the concentration of strong electric field on sharp tips has been described in Wang et al. ${ }^{(7)}$. In the underground level, different ionic solutions can be occupied in small cracks or weak points of XLPE cable and hence water treeing which can cause different stressing in XLPE insulation. But the study of the electric field distribution 
under different ionic solutions in the water treeing is not well known. This does not assure if the XLPE insulations can withstand electric fields under different ionic solutions in water treeing.

This paper has studied the effect of electric field distribution in water treed XLPE insulation under different ionic solutions. The proposed ionic solutions to be used in the study were $\mathrm{Cu}\left(\mathrm{NO}_{3}\right)_{2}, \mathrm{CuSO}_{4}, \mathrm{FeSO}_{4}, \mathrm{~K}_{2} \mathrm{SO}_{4}, \mathrm{Na}_{2} \mathrm{SO}_{4}$, and $\mathrm{NaCl}$. Due to the complexity of the effect, the study was done on bases on simulation. ANSYS MAXWELL 2D has been widely used to analyze electric fields by employing numerical techniques for finding approximate electric fields. ANSYS MAXWELL 2D is a high-performance interactive software package that applies finite element analysis (FEA) to solve electric field and magnetic field problems. Also, it uses meshing process as discretization to transfer continuous functions, models, and equations into discrete counterparts. The first part of the report shows materials and mathematical modeling of electric fields. The second part shows the study of electric fields in XLPE insulation under proposed ionic solutions.

\section{Materials}

\subsection{Power Cable}

A commercial HV power Cable 12/20(24) kV 1 core (XLPE) power cable was used in this study with a cross-section as shown in Fig. 1. Ref. ${ }^{(11)}$ showed more information about this XLPE power cable. This power cable is mostly used in distribution systems in Thailand.

In Fig. 2, circular compact stranded annealed copper conductors have $8.33 \mathrm{~mm}$ diameter, the inner semi-conductive layer has $0.785 \mathrm{~mm}$ thick, cross-linked polyethylene (XLPE) layer has $5.5 \mathrm{~mm}$ thick and outer semi-conductive layer has $0.8 \mathrm{~mm}$ thick. These were the most useful layers in this study.

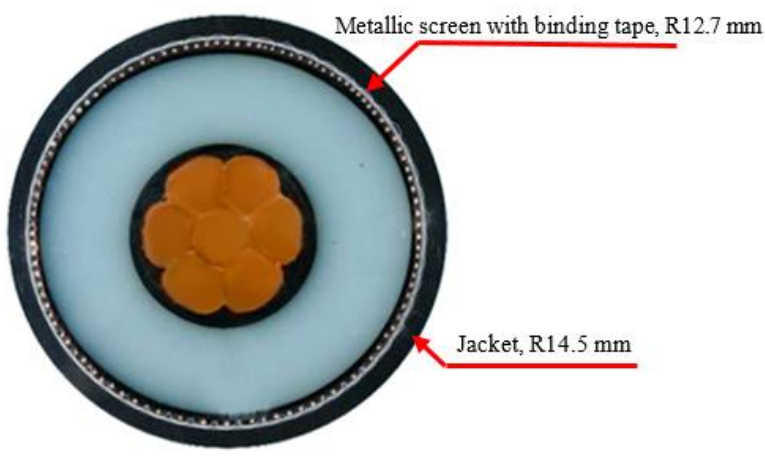

Fig. 1. $22 \mathrm{kV}$ XLPE HV power Cable

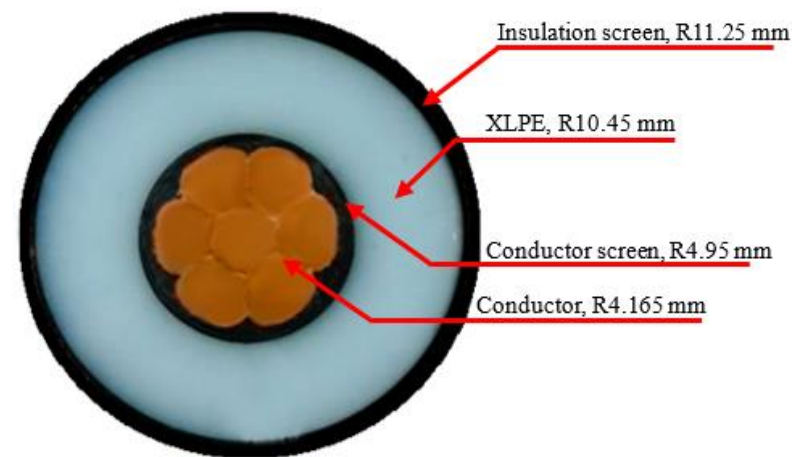

Fig. 2. $22 \mathrm{kV}$ XLPE power Cable with XLPE, inner and outer semiconducting layers

\subsection{Ionic Solutions}

Six ionic solutions were used for the study of electric field i.e. $\mathrm{Cu}\left(\mathrm{NO}_{3}\right)_{2}, \mathrm{CuSO}_{4}, \mathrm{FeSO}_{4}, \mathrm{~K}_{2} \mathrm{SO}_{4}, \mathrm{Na}_{2} \mathrm{SO}_{4}$, and $\mathrm{NaCl}$. The relative permittivity and bulk conductivity of the cross-linked polyethylene (XLPE), semiconductors, copper, and ionic solutions $\left(\mathrm{Cu}\left(\mathrm{NO}_{3}\right)_{2}, \mathrm{CuSO}_{4}, \mathrm{FeSO}_{4}, \mathrm{~K}_{2} \mathrm{SO}_{4}\right.$, $\mathrm{Na}_{2} \mathrm{SO}_{4}$, and $\mathrm{NaCl}$ ) are shown in Table 1.

Table 1. The relative permittivity and bulk conductivity of the materials.

\begin{tabular}{|c|c|c|}
\hline Solution & Relative Permittivity & Bulk Conductivity $(\mathrm{S} / \mathrm{m})$ \\
\hline $\mathrm{Cu}\left(\mathrm{NO}_{3}\right)_{2}$ & 77.66 & 1.391 \\
\hline $\mathrm{CuSO}_{4}$ & 24.5 & 0.535 \\
\hline $\mathrm{FeSO}_{4}$ & 46.19 & 1.036 \\
\hline $\mathrm{K}_{2} \mathrm{SO}_{4}$ & 80.97 & 1.609 \\
\hline $\mathrm{Na}_{2} \mathrm{SO}_{4}$ & 56.96 & 1.405 \\
\hline $\mathrm{NaCl}$ & 30.23 & 1.049 \\
\hline Semiconductor & 100.00 & $2 \times 10^{-3}$ \\
\hline $\mathrm{XLPE}$ & 2.30 & $1 \times 10^{-17}$ \\
\hline Copper & 1.00 & $5.8 \times 10^{7}$ \\
\hline
\end{tabular}

\subsection{Electric Field in an XLPE Power Cable}

A mathematical model of electric fields (E) spreading around an XLPE power cable is presented by the wave equation (Helmholtz's equation) derived from a differential form of Maxwell equations which are Faraday's law and Ampere's law as defined in equations (1) to (9) as given in Chari and Salon ${ }^{(12)}$.

Faraday's law;

$$
\nabla \times \mathrm{E}^{\overrightarrow{ }}=(\partial \mathrm{B} \overrightarrow{)}) / \partial \mathrm{t}
$$

Take the curl $(\nabla)$ of both side, equation (1) become 


$$
\nabla \times\left(\nabla \times \mathrm{E}^{\rightarrow}\right)=-\partial / \partial \mathrm{t}\left(\nabla \times \mathrm{B}^{\rightarrow}\right)
$$

Since $\mathrm{B}$ and $\mathrm{H}$ are related by the constitutive equation

$$
\mathrm{B} \overrightarrow{\mathrm{A}}=\mu \mathrm{H} \overrightarrow{\mathrm{H}}
$$

Then

$$
\nabla \times\left(\nabla \times \mathrm{E}^{\rightarrow}\right)=-\mu \quad \partial / \partial \mathrm{t}\left(\nabla \times \mathrm{H}^{\rightarrow}\right)
$$

Use Ampere's law to replace $\left(\nabla \times \mathrm{H}^{\rightarrow}\right)$ since

$$
\nabla \times \mathrm{H}^{\rightarrow}=(\mathrm{J}) \overrightarrow{+}+(\partial \mathrm{D} \overrightarrow{)} / \partial \mathrm{t}
$$

Then

$$
\nabla \times\left(\nabla \times \mathrm{E}^{\rightarrow}\right)=-\mu \quad \partial / \partial \mathrm{t}(\mathrm{J}) \overrightarrow{-}-\mu\left(\partial^{2} \mathrm{D}^{\rightarrow}\right) /\left(\partial \mathrm{t}^{2}\right)
$$

For isotropic materials, we can use the constitutive equation

Since

$$
\text { (J) } \vec{A}=\sigma \mathrm{E}^{\rightarrow} \text { and } \mathrm{D} \vec{s}=\varepsilon \mathrm{E}^{\overrightarrow{ }}
$$

Then Equation (6) become

$$
\nabla \times\left(\nabla \times \mathrm{E}^{\rightarrow}\right)=-\mu \sigma \quad \partial / \partial \mathrm{t} \mathrm{E}^{\rightarrow}-\mu \varepsilon\left(\partial^{2} \mathrm{E}^{\overrightarrow{ }}\right) /\left(\partial \mathrm{t}^{2}\right)
$$

Using a vector identity for the curl-curl operator, equation (9) become

$$
\nabla \times\left(\nabla \times \mathrm{E}^{\rightarrow}\right)=\nabla\left(\nabla \cdot \mathrm{E}^{\rightarrow}\right)-\nabla \wedge 2 \mathrm{E}^{\rightarrow}
$$

Because the divergence of the electric field is zero in homogeneous material then equation (9) become

$$
\nabla^{2} \mathrm{E}^{\rightarrow}=-\mu \sigma \quad \partial / \partial \mathrm{tE}^{\rightarrow}-\mu \varepsilon\left(\partial^{2} \mathrm{E}^{\rightarrow}\right) /\left(\partial^{2} \mathrm{t}^{2}\right)=0
$$

Where $\varepsilon$ is the dielectric permittivity of media, $\mu$ and $\sigma$ are the magnetic permeability and the conductivity of conductors, respectively.

The electric field in complex form, as in $^{(13)}$ were considered in this paper as time harmonic system, and then,

$$
\partial \mathrm{E} / \partial \mathrm{t}=\mathrm{j} \omega \mathrm{E} \text { and } \quad\left(\partial^{2} \mathrm{E}^{\rightarrow}\right) /\left(\partial \mathrm{t}^{2}\right)=-\omega^{2} \mathrm{E}
$$

Where $\omega$ is the angular frequency then equation (10) becomes,

$$
\nabla^{2} \mathrm{E}^{\rightarrow}-\mathrm{j} \omega \sigma \mu \mathrm{E}^{\overrightarrow{ }}+\omega^{2} \varepsilon \mu \mathrm{E} \vec{\rightarrow}=0
$$

Equation (12) in Cartesian coordinates ( $x, y)$ with the problem in two dimensions, it becomes

$$
\begin{aligned}
& \partial / \partial \mathrm{t}(1 / \mu \partial \mathrm{E} / \partial \mathrm{x})+\partial / \partial \mathrm{y}(1 / \mu \mathrm{E} / \partial \mathrm{y})-(\mathrm{j} \omega \sigma- \\
& \left.\omega^{2} \varepsilon\right) \mathrm{E}=0
\end{aligned}
$$

It is not easy to analyze electric field by using equation (13) in analytical techniques. Equation (13) was used in ANSYS MAXWELL 2D to analyze electric fields.

\subsection{Designing of water treed model in ANSYS Maxwell 2D.}

The geometry of water treeing in XLPE cable was discretized automatically in ANSYS Maxwell 2D as indicated in Fig. 3. The desired field is approximated with a second order quadratic polynomial expressed as in equation (14).

$A_{z}(x, y)=a_{0}+a_{1} x+a_{2} y+a_{3} x^{2}+a_{4} x y+a_{5} y^{2}$

Field quantities inside the triangles were calculated by using second order quadratic interpolation scheme. The Poisson's equation as equation (15) is replaced with energy functional in equation (16). This function is minimized with respect to each node in every triangle.

$$
\begin{aligned}
& \nabla^{2} \mathrm{~A}=-\mu \mathrm{J} \\
& \mathrm{F}(\mathrm{A})=1 / 2 \quad \int((\nabla \mathrm{A} \cdot \nabla \mathrm{A}) / \mu+\mathrm{AJ}) \mathrm{dV}
\end{aligned}
$$

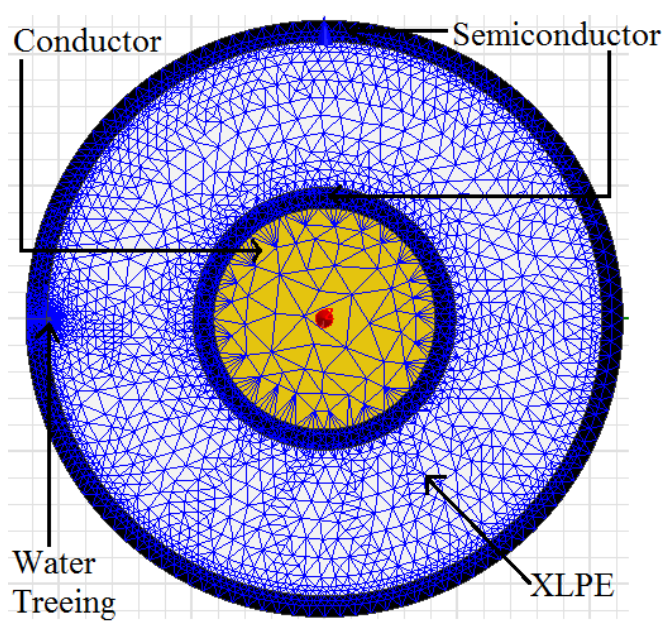

Fig. 3. Discretized water treed XLPE Cable

\section{Simulation Results}

The results of electric fields distributions with Bush and Vented type water treeing of radius $\mathrm{r}_{0} 0.1 \mathrm{~mm}, 0.5 \mathrm{~mm}$, $1.0 \mathrm{~mm}$ and $1.5 \mathrm{~mm}$ with $\mathrm{Cu}\left(\mathrm{NO}_{3}\right)_{2}, \mathrm{CuSO}_{4}, \mathrm{FeSO}_{4}, \mathrm{~K}_{2} \mathrm{SO}_{4}$, $\mathrm{Na}_{2} \mathrm{SO}_{4}$, and $\mathrm{NaCl}$ ionic solutions are shown in Fig. 4 and Fig. 5 respectively. In Fig 4 and 5, the thickness of layers from inner to outer semiconductor is represented in $\mathrm{x}$-axes. 


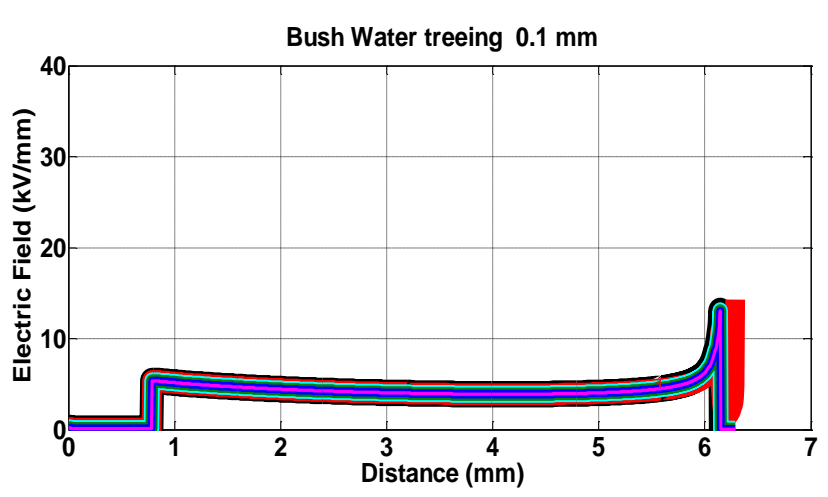

(a) bush water treeing $0.1 \mathrm{~mm}$

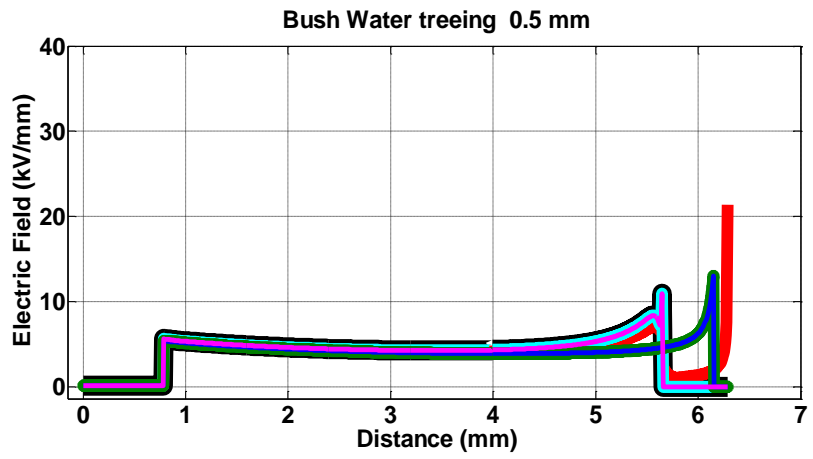

(b) bush water treeing $0.5 \mathrm{~mm}$

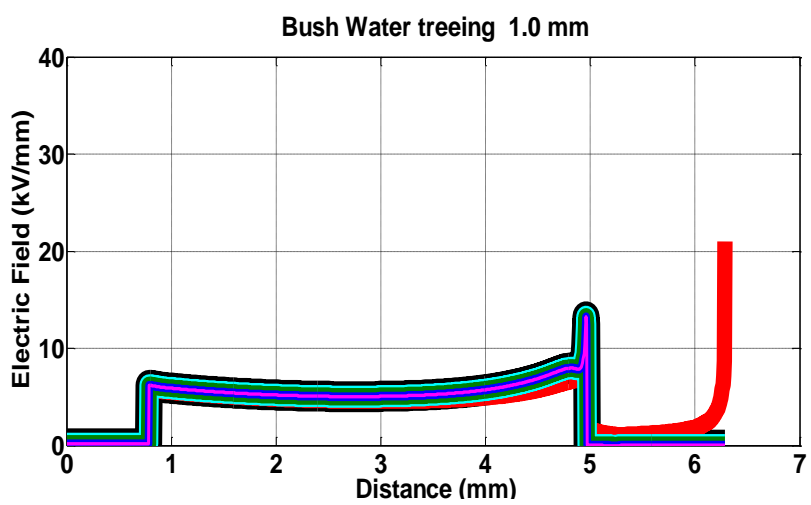

(c) bush water treeing $1.0 \mathrm{~mm}$

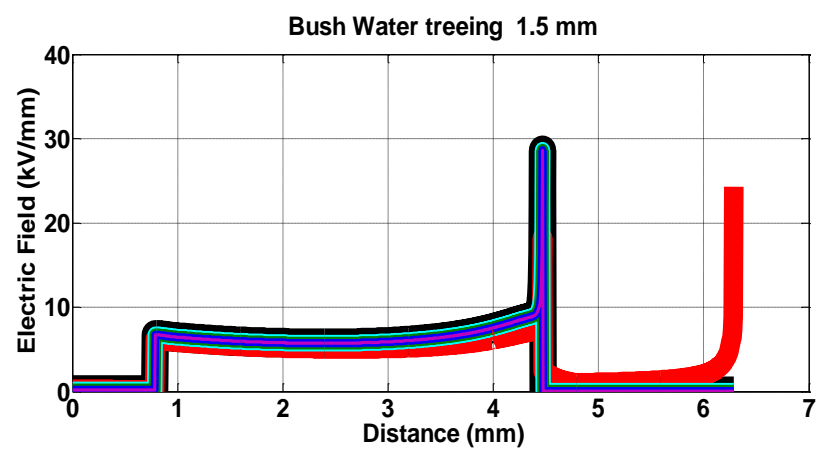

$=\mathrm{Cu}\left(\mathrm{NO}_{3}\right)_{2}=\mathrm{CuSO}_{4}-\mathrm{FeSO}_{4}=\mathrm{K}_{2} \mathrm{SO}_{4}=\mathrm{Na}_{2} \mathrm{SO}_{4}=\mathrm{NaCl}$

(d) bush water treeing $1.5 \mathrm{~mm}$

Fig. 4. Electric field distribution in bush type water treeing

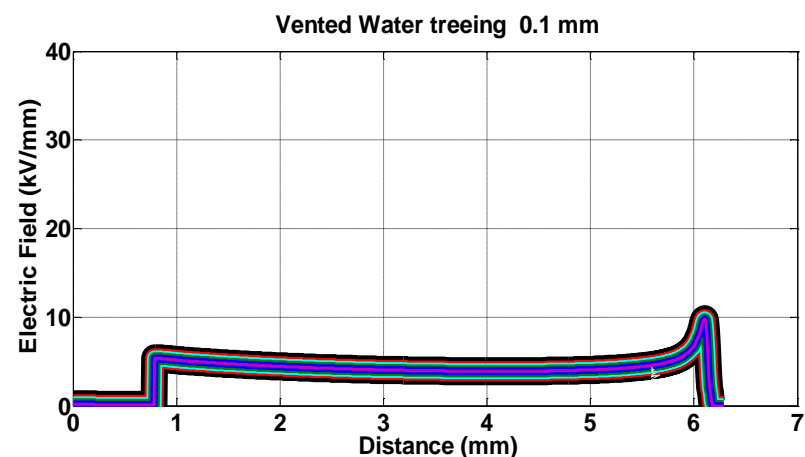

(a) vented water treeing $0.1 \mathrm{~mm}$

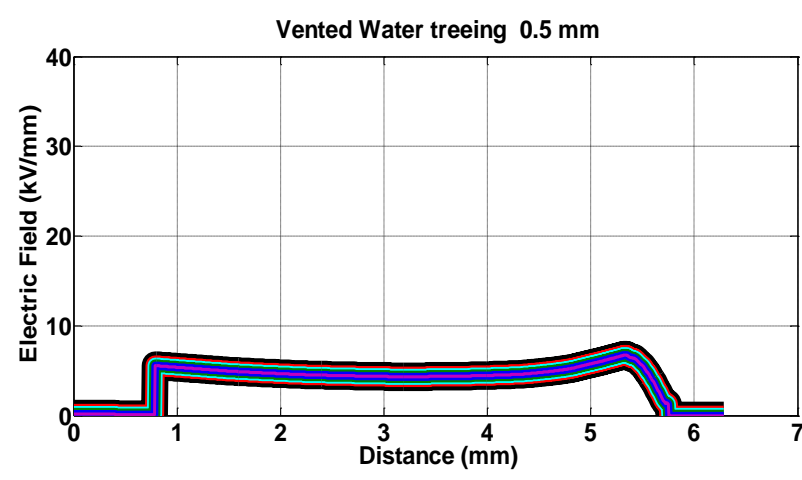

(b) vented water treeing $0.5 \mathrm{~mm}$

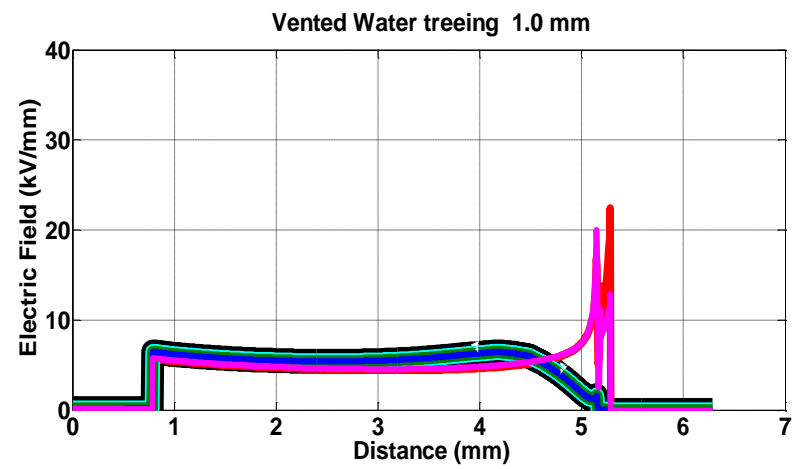

(c) vented water treeing $1.0 \mathrm{~mm}$

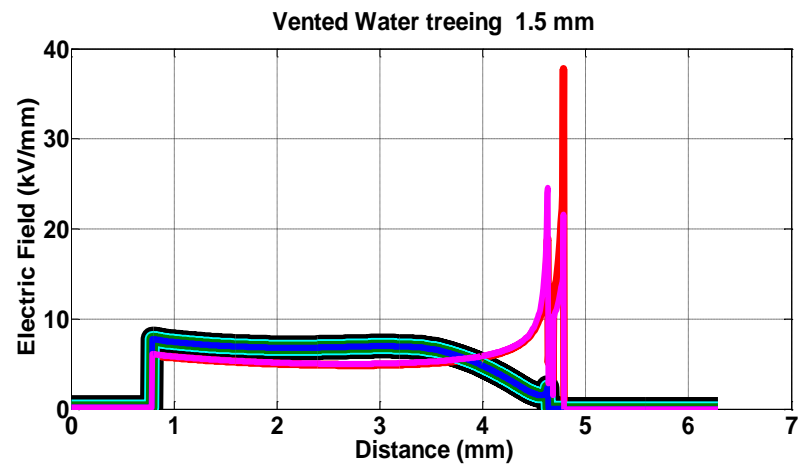

$\mathrm{Cu}\left(\mathrm{NO}_{3}\right)_{2}=\mathrm{CuSO}_{4}-\mathrm{FeSO}_{4}=\mathrm{K}_{2} \mathrm{SO}_{4}=\mathrm{Na}_{2} \mathrm{SO}_{4}=\mathrm{NaCl}$

(d) vented water treeing $1.5 \mathrm{~mm}$

Fig. 5. Electric field distribution in vented type water treeing 


\section{Discussion of Results}

From Fig. 4, the maximum field strength of approximately $31 \mathrm{kV} / \mathrm{mm}$ was observed in a treeing radius of $1.5 \mathrm{~mm}$ with $\mathrm{Cu}\left(\mathrm{NO}_{3}\right)_{2}, \mathrm{FeSO}_{4}, \mathrm{~K}_{2} \mathrm{SO}_{4}, \mathrm{Na}_{2} \mathrm{SO}_{4}$, and $\mathrm{NaCl}$. In Fig. 5, the maximum field strength of approximately $38 \mathrm{kV} / \mathrm{mm}$ was observed in a treeing radius of $1.5 \mathrm{~mm}$ with $\mathrm{CuSO}_{4}$. The maximum value of field strength in Fig 4 and 5 was seemed to exceed minimum field strength of XLPE insulation $(30 \mathrm{kV} / \mathrm{mm})^{(14)}$.

From the observation, vented water treeing was seen to exceed minimum field strength of XLPE insulation earlier than bush type water treeing. El-Zein et al ${ }^{(15)}$ presented the study of electrical trees in solid insulation and showed that vented water treeing may occur sooner compared to bush water treeing. Furthermore, the presence of $\mathrm{CuSO}_{4}$ ionic solution showed the greatest influence in vented type water treeing. The disposition of $\mathrm{CuSO}_{4}$ ionic solution in vented treeing and hence exalt considerably was also presented in Boonraksa ${ }^{(16)}$. Therefore, an environment with $\mathrm{CuSO}_{4}$ ionic solutions may result in high service cost due to the performance of vented water treeing.

\section{Conclusions}

Effects of ionic solutions in the propagation of water treeing in HV XLPE cable have been presented. Bush and vented water treeing with treeing of radius $r_{0}$ of $0.1 \mathrm{~mm}, 0.5$ $\mathrm{mm}, 1.0 \mathrm{~mm}$ and $1.5 \mathrm{~mm}$ under the effects of $\mathrm{Cu}\left(\mathrm{NO}_{3}\right)_{2}$, $\mathrm{CuSO}_{4}, \mathrm{FeSO}_{4}, \mathrm{~K}_{2} \mathrm{SO}_{4}, \mathrm{Na}_{2} \mathrm{SO}_{4}$, and $\mathrm{NaCl}$ ionic solutions were clearly designed in ANSYS MAXWELL 2D software. Electric field strength of $38 \mathrm{kV} / \mathrm{mm}$ and $31 \mathrm{kV} / \mathrm{mm}$ in treeing radius of $1.5 \mathrm{~mm}$ were observed in vented and bush water treeing respectively. Observed maximum field strength was seen to exceed minimum field strength of XLPE insulation $(30 \mathrm{kV} / \mathrm{mm})$. Moreover, vented was investigated to occur in lower electric fields compared to bush water treeing. Therefore, $\mathrm{CuSO}_{4}$ ionic solution revealed to exhibit much contribution in the advancement of water treeing.

\section{References}

(1) Arora, R., and Mosch W.: "High Voltage and Electrical Insulation Engineering”, ISBN: 978-0-470-60961-3, Wiley-IEEE Press, pp. 319-369, 2011

(2) Marungsri, B., Rawangpai, A., and Chomnawang N.: "Investigation Life Time Model of $22 \mathrm{kV}$ XLPE Cable for Distribution System Applications in Thailand", WSEAS Transactions on Circuits and Systems, Vol. 10, No. 2, pp. 185-197, 2011

(3) Jayakrishnana, A., Kavithab, D., Arthi, A., Nagarajana, N., and Balachandrana M.: "Simulation of electric field distribution in nano dielectrics based on XLPE", Materials Today, Vol. 3, No. 6, pp. 2381-2386, 2016

(4) Mauseth, F., Amundsen, M., Lind, A., and Faremo H.: "Water tree growth of wet XLPE insulation stressed with DC and high frequency AC", Electrical Insulation and Dielectric Phenomena (CEIDP), pp. 692-695, 2012

(5) Fabiani, D., Cavallini, A., Montanari, G. C., Saccani, A., Toselli, M., and Pilati F.: "Hybrid nanostructured coating of XLPE insulation: Effect on partial discharge activity", Electrical Insulation and Dielectric Phenomena (CEIDP), pp. 315-318, 2012

(6) Danikas, M. G., and Tanaka, T.: "Nanocomposites-a review of electrical treeing and breakdown", IEEE Electrical Insulation Magazine, Vol. 25, No. 4, pp. 19-25, 2019

(7) Wang J., Wu J., Li Y., and Zheng X.: "Simulation of electric field distributions in water treed XLPE using finite element method", Engineering and Technology (S-CET), pp. 1-4, 2012

(8) Boggs, S., Densley, J., and Kuang J.B.: "Mechanism for impulse conversion of water trees to electrical trees in XLPE”, IEEE Trans on Power Delivery, Vol. 13, No. 2, pp. 310-315, 1998

(9) Assay, D., Kurimoto, M., Komori, F., Kato1, T., Funabashi, T., and Suzuoki Y.: "Influence of AC Voltage Prestressing on AC Electrical-tree Inception of Deteriorated LDPE with Dried Water-tree", 2014 Annual Report Conference on Electrical Insulation and Dielectric Phenomena, pp. 385-388, 2014

(10) Elfrith Foottit : "Statistical, Electrical and Mathematical Analysis of Water Treed Cross-Linked Polyethylene Cable Insulation”, Doctoral Thesis, pp. 1-20, 2015

(11) Bangkok Cable (2014) Online document: [www.bangkokcable.com/product/backoffice/.../14052 8_12-20(24) kV_CV_1core.pdf]

(12) Chari, M.V.K., and Salon, S.J.: "Numerical Methods in Electromagnetism", Academic Press, 2019.

(13) Christopoulos, C.: “The Transmission-Line Modeling Method", IEEE Press, 1995

(14) Bangkok Cable (2014) Online document : [www.bangkokcable.com/product/backoffice/file_uplo ad/PartA_Technical_Data.pdf] 
(15) El-Zein, A., EL Bahy, M.M, and Talaat, M.: "Types of electrical trees in solid insulation under electrical and mechanical energy basis", 2008 12th International Middle-East Power System Conference, pp. 80 - 84, 2008

(16) Boonraksa, T., and Marungsri, B.: "Role of Ionic Solutions Affect Water Treeing Propagation in XLPE Insulation for High Voltage Cable", International Journal of Electrical, Computer, Energetic, Electronic and Communication Engineering, Vol. 8, No. 5, pp. 788-791, 2014. 